\title{
Using IS-LM Model to Analyze the Effects of Covid-19 on Chinese Economy
}

\author{
Haonan Wang \\ YGQ School of Beijing, Beijing, 102600, China \\ TSINGLIN Practice Platform \\ Managing the Macroeconomy: Business Cycles, Monetary and Fiscal Policy \\ Corresponding author's e-mail: Vivian.wang@cas-harbour.org
}

\begin{abstract}
Covid-19 has affected Chinese economy greatly. Each local industries and companies are influenced by the isolation policy, and people are losing jobs. Because most industries and companies are affected, the GDP growth rate of the first quarter in 2020 have decreased a lot. After discussing how does the quarter GDP growth rate decrease detailed, the theory that coronavirus influenced Chinese economies significantly, will be proved by IS-LM model through accurate data from National Bureau of Statistics and other statistics by using formula equations. Those statistics will show the change of each element of the financial market and goods market, which are corresponding to each variable in the formula of IS-LM model. The changes in these variables give the expectation of how economy changes over time. According to the analysis in this paper, coronavirus has brought huge impact on the net export, the investment inboard and aboard, and the employment as well as salaries, leading to an overall decrease in output and the nominal interest rate. Therefore, both the goods markets and the financial markets are affected through the pandemic, corresponding to the situation in China at the first quarter of 2020.
\end{abstract}

Keywords: Covid-19, IS-LM model, Quarter GDP growth rate, Local Industry, Isolation policy

\section{INTRODUCTION}

The Global epidemic, Covid-19, has been caused severe situation all over the world. High mortality rate of covid-19 and the policy of isolation have bringing significant impact to the local industries. Companies are closed down and people are losing jobs, leading to a great decrease to the economy. Being one of the biggest economies in the world, China have undergone huge impact to the modest economy, although the epidemic has been controlled by the Chinese government quickly. According to the National Bureau of Statistics (2020), the GDP growth rate in the second quarter in 2020 has been decreased greatly, with a growth rate of -6.8 percent compared with the same quarter last year. The local Industries also have been decreased, especially for the accommodation and catering with a growth rate of -18 percent compared with last year. This paper will be using IS-LM model, a model that could give obvious graph to show the relationship and the trend in the economy using data of each variables, to analyze how does Covid-19 influences Chinese Industries and economies, using the basic formula of IS-LM model and matching the data organized with the element in the formula. The reason why does IS-LM model is being used is that the model could provide the most obvious trend of the economy; It could also tell that which element in economy have been greatly influenced through the epidemic, giving one of the most detailed information of how each economy change. In an overview, the paper will firstly discuss the relationship between epidemic and isolation policy, which will come to the reason why the local Industry and Company are affected. Then, data matching with the element in the formula of IS-LM model will be analyzed, showing how these changing elements influencing the economy. By analyzing Chinese economy by IS-LM model, people can know which element are influenced throughout the coronavirus, and government may apply more specific policy to each element of the economy, for example, the nominal income, the net export, and the investment, to minimize the influence the epidemic brought to the economy. 


\section{EFFECTS OF COVID-19 ON THE LOCAL INDUSTRIES}

Due to the extreme high infectivity and high mortality, the Chinese government applied policy of quarantine, in which people were not suggested to go out or move to another city. The action has caused strong impact to some local industries and companies, for example, tourism, accommodation, and catering have been strongly affected because of low volume of commuters. According to the National Bureau of Statistics (2020) [1], the GDP growth rate of accommodation and catering in the first half of 2020 have decreased to -18 percent compared with the same period of time in last year. In addition to the low volume of commuters, the cost of transportation in the country increased, bringing negative effects to all companies and industries that rely on transportation. Moreover, most factories are forced to close down due to Covid-19, causing a great problem to most of the manufacturing industries in China, and the manufacturing industries play an important role in Chinese GDP. According to the data from KUAIYI Network [2], the proportion of added value of manufacturing industry in GDP in China is 27.17 percent. Thus, the impact on manufacturing industries greatly influences the total GDP all over the country.

\section{EFFECTS OF COVID-19 ON THE IMPORT AND EXPORT}

Since the first month of 2020, when the situation in China becomes uncontrollable, many countries setting up policies that prevent the import and export from China. For example, "No Entry" and "No Air traffic" have been applied first by the U.S. government, leading to a considerable decline to the export and import in China. The decline makes the cooperation relying on the export and import a tough time that orders for good from other countries are cancelled, and the goods import are constrained, leading to additional difficulties for the modest manufacturing industries that depend on the import product to re-process. According to Liao Maolin and Zhang Mingyuan (2020) [3], the Associate researcher from Institute of urban development and environment In Chinese Academy of Social Sciences and the Doctoral candidate of Chinese Academy of Social Sciences, China's total import and export volume reached 11.54 trillion yuan, down 4.9\%. Among them, compared with the same period last year, exports decreased by $4.7 \%$. Thus, the impact on import and export have significant effects to Chinese total GDP.

\section{EFFECTS OF COVID-19 ON UNEMPLOYMENT}

Because Factories and companies are closing down, many people lose their job during this pandemic. According to the data from According to ZHANG Yi
(2020) [4], the Director of the Department of population and employment statistics in National Bureau of Statistics, the unemployment rate rose to $6.2 \%$ corresponding to the urban national survey. The rising unemployment rate lead to the decline the nominal income and the overall GDP in the first half of 2020, bringing negative effects to the Chinese economy.

\section{IS-LM MODEL}

IS-LM model is a model of economic analysis created by a famous modern British economist John Richard Hicks and the founder of Keynesian school in America Alvin Hansen. The model is concluded by the fundamental of Keynesian macroeconomic theory. The IS-LM model is used to describe the theoretical structure of the interrelationship between product market and money market. In the product market, the national income is determined by the consumption $\mathrm{C}$, the investment $\mathrm{I}$, the government spending $\mathrm{G}$, and the net export $\mathrm{X}-\mathrm{M}$. The investment is affected by the interest rate, $\mathrm{i}$, given by the money market. Comparatively, the interest rate is usually influenced by the National Income, which would affect the money demand. This shows the interrelationship between product market and money market, and IS-LM model is the tool analyzing the structure between these two markets, solving problems in macroeconomics.

\section{USING IS-LM MODEL TO ANALYZE THE ECONOMY IN CHINA}

IS curve is determined by the output $\mathrm{Y}$ and the interest rate. The equation of Output, $\mathrm{Y}$, is given by the formula $\mathrm{Y}=\mathrm{C}(\mathrm{Y}-\mathrm{T})+\mathrm{I}+\mathrm{G}$. According to $\mathrm{LI}$ Xin-tong [5], the graduate student of Business School of Jilin University, and FANG Yi (2020) [5], the professor of quantitative economy research center and Business School of Jilin University, China's fixed asset investment was 19919.4 billion yuan with a decrease rate of 6.3 percent compared with last year. This decline is caused by the difficulties of transportation, the tough situation of attracting investment and the lack of labours. This led to the decrease in Investment I, in which makes the output to decrease. According to FANG Yi and LI Xin-tong (2020) [5], the total Retail of Consumer Goods is 13873 billion yuan, decreasing the overall consumption, $\mathrm{C}$, in the society. The decrease in $\mathrm{C}$ would also leads to a decline of the output. According to FANG Yi and LI Xin-tong (2020) [5], China's total imports and exports would be 11.54 trillion yuan, with a decrease rate of 4.9 percent, corresponding to the decrease in net export. Once the net export is decreased, the total demand for goods, $\mathrm{Z}$, decrease at the same time. Considering $\mathrm{Z}=\mathrm{Y}$, the decline of export and import would influence the output as well. These variables would reduce the output. Giving the unchanged interest rate, i, the IS curve would shift to the left, proving by fig. 1 below. 


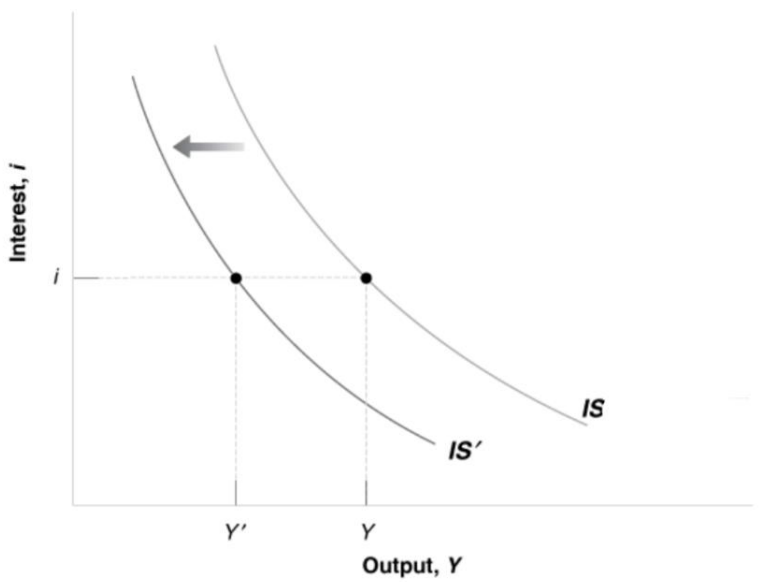

Figure 1 Decrease in output leads the IS curve to shifts to the left

Source: Ascari (2020)

Based on fig.1, the unchanged interest rate $i$ and the decreased output $Y$ would make the IS-curve to shifts to the left. Meanwhile, great decline in the nominal income caused by Covid-19 would decrease the nominal income. With a stable interest rate, the decline in nominal income would decrease the demand for money as well as the money supply. This can be shown by fig. 2 given blow.

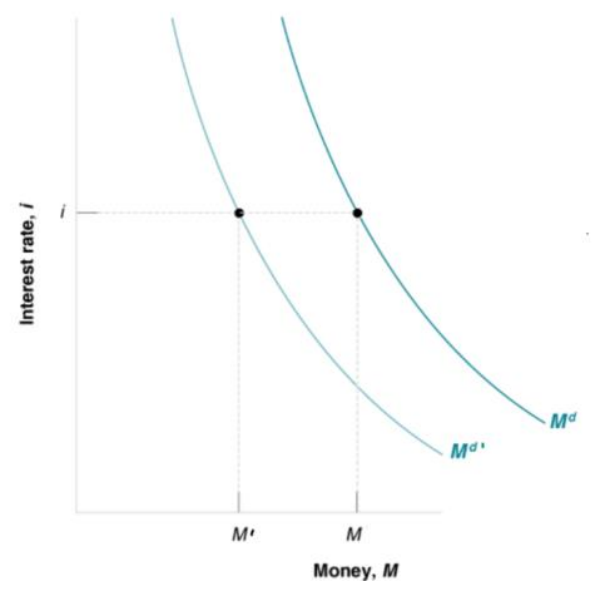

Figure 2 Decrease in nominal income shifts the money demand curve to the left

Source: Ascari (2020)

According to fig.2, with an unchanged interest rate, the money demand curve, Md, shifts to the right, which makes the money supply, $\mathrm{M}$, to decrease. The relationship between demand of money and money supply could come up with another important formula in IS-LM model, the LM relation. LM relation occurred when money demand and money supply reach equilibrium. When these two elements reach equilibrium $\mathrm{A}$, if the nominal income $\mathrm{Y}$ decreases, the interest rate would decrease at the same time, showing by fig. 3 below. On the other hand, the increase in the interest rate would lead to the increase in the output.

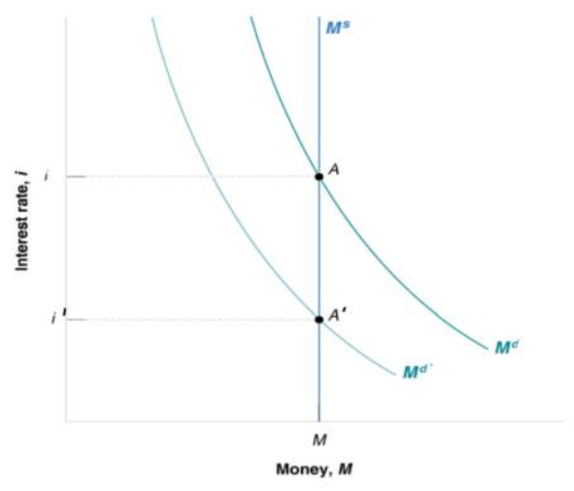

Figure 3 The shifts in money demand curve will decrease the nominal interest rate

Scource: Ascari (2020)

The equilibrium in the goods market, which is represent by IS-curve, implies that the decrease in the output leads to the increase in interest rate, and the LM-curve implies that an increase in interest rate leads to an increase in the output at the same time. According to fig. 4 below, only at point $\mathrm{A}$, in which both curves crosses the same point, goods markets and financial markets are in equilibrium.

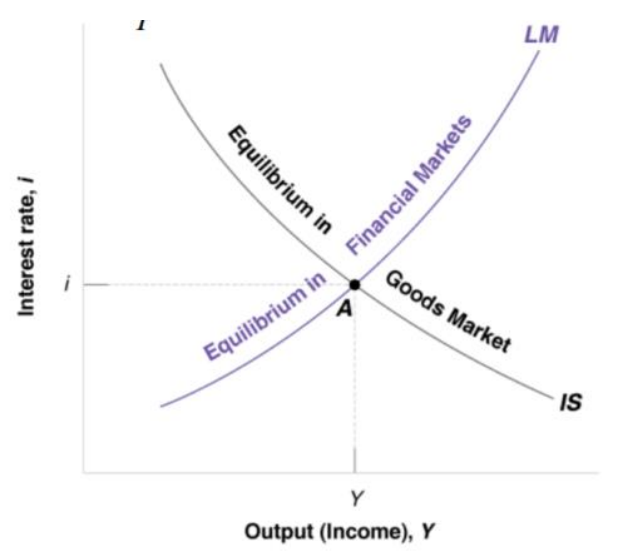

Figure 4 The equilibrium between LM curve and IS curve

Source: Ascari (2020)

The relationship between IS curve and LM curve shows that the decrease in output would lead to the increase in interest rate based on the IS-curve, however, an incline in interest rate would stimulate the output based on the LM curve, proving by fig. 5 below. 


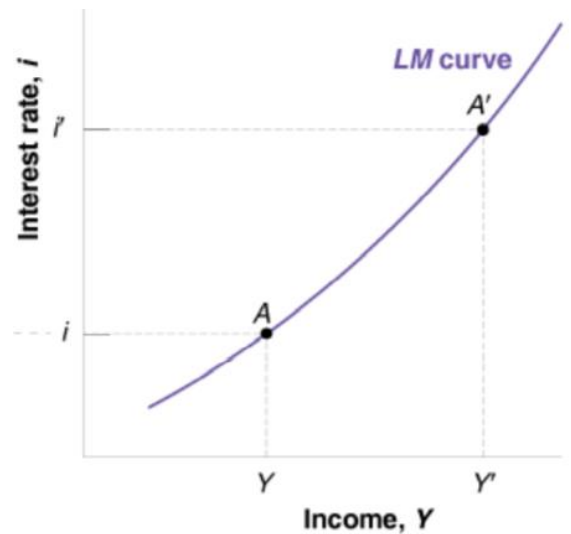

Figure 5 Increasing interest rate would increase the nominal income

Source: Ascari (2020)

The future trend of increasing output, Y, could corresponds to the influences caused by Covid-19, that the economic upturn will appear immediately once the epidemic has been controlled fully and the various industries begin to operate, recovering the economic depression as fast as possible. Even if the epidemic has not been controlled, the decline in interest rate would still minimize the loses from the pandemic.

\section{CONCLUSION}

The global epidemic, Covid-19, have caused great impact to every economy all over the world. Coronavirus brings huge effects to the local industries and companies, and it also cause a rising unemployment rate. All of these factors lead to the depression in the economy, that the decline in investment, nominal income, and net export lead to considerable economic loses for the country. In China, because the investment and net export were constrained by the policy of other countries, the investment and the export and import decreased badly. Moreover, due to the policy of quarantine, people could not work in the factory or the company for a long time, and the costs of transportation increase greatly, leading to a great depression to the local industries, causing a huge decline in GDP growth. However, based on the IS-LM model, the decrease in the overall output would leads to the increase in the interest rate. According to the LM-curve, the increase in the nominal interest rate would increase the output, which would finally push the economy to recover quickly to reach a equilibrium in both goods markets and financial markets. Before the situation starts to get better, the increase in interest rate will lead to a surge in output, lowering the effects of Covid-19 on the economy. Thus, accelerating vaccine research would be the first thing the government should consider to minimize the death from the epidemic because starting work too early would not recover the economy but prolong the epidemic, considering the goods markets and the financial markets would recover themselves effectively. In addition, enhancing the co-operation and trade after the pandemic between different countries could greatly increase the speed of economic upturn, making the whole society becoming better and better.

\section{ACKNOWLEDGMENT}

Thanks to China national knowledge internet for giving such plentiful resources and passages relevant to the recent situation of Chinese economy and Covid-19. The National Bureau of Statistics also provides accurate and detailed data of GDP changes in 2020 in China, which gives the basic data support to the paper.

\section{REFERENCES}

[1] Kuai Yi Financial Network. (n.d.). The proportion of added value of China's manufacturing industry in GDP over the years. https://www.kylc.com/stats/global/yearly_per_cou ntry/g_manufacturing_value_added_in_gdp/chn.ht $\mathrm{ml}$

[2] National Bureau of Statistics, (2020, Jul 17). Preliminary calculation results of gross domestic product (GDP) in the second quarter and the first half of 2020.

http://www.stats.gov.cn/tjsj/zxfb/202007/t202007 17_1776516.html

[3] M. Liao, M. Zhang. The Impact of COVID-19 Epidemic on China's Economic Growth. Fujian Tribune, 2020, (04), 25-33.

[4] Y. Zhang. ZHANG Yi: the employment situation has improved with the resumption of work and production, and it has the basis and conditions to maintain stability under pressure. National Bureau of Statistics. April 19, 2020.

http://www.stats.gov.cn/tjsj/zxfb/202004/t202004 19_1739680.html

[5] X. Li, Y. Fang. Research on the Impact of COVID-19 on Chinese Economy and Countermeasure. Journal of Changchun Finance College, 2020, (04), 78-87.

[6] G. Ascari. The IS-LM model. [Graphs in PowerPoint slides]. UNIVERSITA DI PAVIA Department of Economics and Management. July $22,2020$. 